\title{
Can a reduced rate of herbicide benefit native plants and control ground cover weeds?
}

\author{
Kate G. McAlpine ${ }^{1 *}$, Shona L. Lamoureaux ${ }^{2}$, Susan M. Timmins ${ }^{1}$, Debra M. Wotton ${ }^{1,3,4}$ \\ ${ }^{1}$ Department of Conservation, PO Box 10420, Wellington 6143, New Zealand \\ ${ }^{2}$ AgResearch Ltd, Private Bag 4749, Lincoln 8140, New Zealand \\ ${ }^{3}$ Present address: Moa's Ark Research, PO Box 11270, Wellington 6142, New Zealand \\ ${ }^{4}$ Biological Sciences, University of Canterbury, Private Bag 4800, Christchurch 8140, New Zealand \\ *Author for correspondence (Email: kmcalpine@doc.govt.nz)
}

Published online: 19 June 2018

\begin{abstract}
The use of herbicide to control weeds in natural areas can cause non-target damage to resident native plant communities and compromise native restoration goals. We tested 'full' and 'reduced' (half) rates of herbicide (rates based on previous glasshouse trials) on the ground cover weed species tradescantia (Tradescantia fluminensis), plectranthus (Plectranthus ciliatus), and climbing asparagus (Asparagus scandens) to determine whether the reduced rate would cause less non-target damage to natives and achieve sufficient control of the weeds. We also included a manual removal (hand-weeding) treatment, and experimental control (non-treatment). These four treatments were applied to dense ground cover weed infestations at six lowland forest sites. Subsequent responses of the ground cover weed, native and other exotic plant species were monitored for 24 months. Two months after treatment, biomass of all three weed species was reduced to extremely low levels across all treatments relative to controls. Twenty-four months after treatment, biomass of plectranthus remained low, but tradescantia and climbing asparagus had recovered to near pre-treatment biomass levels across all treatments. Recovery of tradescantia was positively correlated with canopy openness. The reduced rate of herbicide gave a similar level of weed control to the full rate, across all three weed species, however repeat treatments appear necessary for sustained control of tradescantia and climbing asparagus. At sites invaded by plectranthus, the reduced rate of herbicide also increased native species richness. However, herbicide treatments had no effect on native plant abundance or native species richness at sites invaded by tradescantia and climbing asparagus. Manual removal sometimes benefited native plants, but all treatments increased abundance and/ or species richness of other exotic plant species at some sites. Generally, native plant abundance and native species richness decreased with increasing canopy openness, while the opposite was true for exotic species. This study provides evidence that, although repeat applications are likely necessary, a reduced rate of herbicide can benefit native plants and achieve ground cover weed control. Further research to fine-tune these results and extend them to other ground cover weed species would be invaluable.
\end{abstract}

Keywords: herbicide dose; invasive species; native plants; non-target damage; restoration; weed control

\section{Introduction}

Environmental weeds (sensu Falk-Petersen et al. 2006) cause a myriad of negative impacts in natural environments throughout the world, including reductions in native plant abundance and native species richness. Concerns about these impacts prompt aggressive, sustained control programmes, often involving the broad-scale application of herbicide (Kettenring \&Adams 2001). A common assumption is that higher rates of herbicide result in better weed control, but this is not necessarily true; there are many examples where a high rate of herbicide has provided no better control than a lower rate of herbicide (e.g. Sheley \& Denny 2006; Endress et al. 2008). This may be because dosage rate is just one of many factors that affect herbicide performance; others include timing of treatment, climatic conditions, and traits of the target weed species (Kudsk 2008).

In natural systems, the application of high rates of herbicide can cause significant non-target damage to co-existing native plants, which in turn can lead to conditions that allow re-invasion of the same or different weed species (Matarczyk et al. 2002; Flory 2010; Skurski et al. 2013; Kuebbing \& Nuñez 2015). Certain herbicide formulations, or those with long soil residual times may also pose a greater risk of non-target damage to natives (Katagi 2004; Harrington \& Schmitz 2007). In a New Zealand example, Standish (2002) suggested that residual herbicide could be delaying native seedling establishment by 4-6 months following weed control. Manual control methods such as hand weeding eliminate the need for herbicide and can be applied more selectively, but are slow and labour intensive, and thus often impractical. Manual control methods may also result in more soil disturbance than herbicide control, which can be associated with increased exotic invasion (Kettenring \& Adams 2001; D’Antonio \& Meyerson 2002).

There is considerable public appetite forminimising herbicide use, due to concerns about the potential environmental and human health impacts of herbicide. In agricultural systems, it has been shown that herbicide rates can sometimes be reduced well below recommended rates without loss of efficacy (Blackshaw et al. 2006; Kudsk 2008). However, there are concerns that this practice may have contributed to the evolution of herbicide resistance in agricultural systems, and it is not widely recommended (Neve \& Powles 2005; Manalil et al. 2011). The published literature on herbicide application rates pertains almost exclusively to agricultural weeds, and in most cases, recommended application rates for environmental weeds are not stated on herbicide labels. Accordingly, there is considerable uncertainty around what herbicide application rates are required for effective control of environmental weeds in New Zealand and elsewhere. 
Site-specific biotic and abiotic conditions can also play a role in the success or failure of weed control, and in the subsequent recovery of resident plant species. Many studies have shown that light and soil moisture availability, for example, can strongly influence both recovery of the target weed and the responses of native and other exotic species to weed control (Cabin et al. 2002b; Standish 2002; Hansen \& Wilson 2006; Loh \& Daehler 2008; Flory 2010). Removing the target weed may also change conditions such as light availability or soil chemistry, thereby indirectly influencing subsequent weed or native recovery (e.g. D'Antonio et al. 1998; Cabin et al. 2002a; Thaxton et al. 2012). If site-specific conditions alter the effectiveness of weed control treatments and/or the responses of resident plant species, multiple management plans may needed for single weed species (Flory 2010).

Widespread ground cover weed species such tradescantia (Tradescantiafluminensis) and climbing asparagus (Asparagus scandens) have well-documented negative impacts on native plant communities in New Zealand (Kelly \& Skipworth 1984a; Standish et al. 2001; McAlpine et al. 2017), and are thus frequently targeted in weed control programmes. At sites with few native species in the understory, non-target damage may not be a problem. However, studies have recorded a diverse range of native species coexisting with these ground cover weeds (Standish et al. 2001; McAlpine et al. 2015), so it may be difficult to avoid non-target damage when applying herbicide at such sites.

The effects of herbicide and manual control treatments on tradescantia and co-occurring native species have been reasonably well-studied, with varying results. Several studies have shown that tradescantia biomass can be reduced by both herbicide and manual control treatments, but it recovers quickly if removal is incomplete (Kelly \& Skipworth 1984b; Standish 2002; Hurrell et al. 2009). A survey of 36 forest managers around New Zealand found that approaches to controlling tradescantia varied in terms of the methods and herbicides used, but typically involved repeated applications of herbicide (Lusk et al. 2012). Hurrell et al. (2009) tested a range of herbicide rates on tradescantia and found that higher rates of herbicide were more effective at removing tradescantia biomass, but regrowth of tradescantia occurred regardless of the rate of herbicide used, and occurred sooner where a lower herbicide rate was used. In terms of effects of tradescantia control treatments on native plant communities, Standish (2002) found that native plant survival decreased in herbicide-treated plots compared to hand-weeded and untreated plots, whereas Hurrell et al. (2008) found no evidence that herbicide rate influenced native seedling numbers or timing of emergence. There appear to be no published New Zealand field studies on the control of other ground cover weed species.

Although a high level of ground cover weed control is possible with one treatment, recovery of the weed appears likely, and managers would usually assume that multiple treatment applications would be required for sustained control (e.g. Standish 2002; Hurrell et al. 2009). However, the first application of any given control treatment is perhaps the most important application, given that the resulting weed control and non-target damage is the starting point for what happens next. Too little herbicide (or other removal treatment) may allow rapid recovery of the weed, but too much herbicide may cause excessive non-target damage to natives; the key is getting the balance right, particularly at sites where a return to native dominance is the desired outcome. Thus, while recognising that multiple treatment applications are likely necessary for long-term control of ground cover weeds, the focus of the current study was to compare weed and native responses to the initial control treatments. Specifically, we tested the efficacy of two herbicide rates and a manual removal treatment on the control of ground cover weeds in the field, and monitored post-treatment responses of co-occurring native and exotic plant species.

\section{Methods}

\section{Sites}

Six lowland native forest sites where the ground layer vegetation (approx. $<500 \mathrm{~mm}$ height) was dominated by a single species of ground cover weed were identified in the Bay of Plenty area of the North Island, New Zealand (the same sites as in McAlpine et al. 2015). Vegetation was predominantly native broadleaved-podocarp secondary forest, although a few exotic conifers were present at some sites. Two sites were found for each of three common ground cover weed species: climbing asparagus (Asparagus scandens Thunb., Asparagaceae), plectranthus (Plectranthus ciliatus E. Mey., Lamiaceae), and tradescantia (Tradescantiafluminensis Vell., Commelinaceae). Tradescantia and climbing asparagus are widespread throughout New Zealand, whereas plectranthus is more patchily distributed (Howell \& Terry 2016). Across the six sites, mean annual temperature range is $9.9-18.7^{\circ} \mathrm{C}$ and mean annual precipitation is $1436 \mathrm{~mm}$ (NIWACliFlo database: http://cliflo.niwa.co.nz). Mean elevation ranged from 55 to 270 m a.s.l., latitude ranged from $37^{\circ} 25^{\prime}$ to $37^{\circ} 59^{\prime} \mathrm{S}$, and longitude ranged from $175^{\circ} 43^{\prime}$ to $176^{\circ} 02^{\prime} \mathrm{E}$. For further details of sites and ground cover weed species see McAlpine et al. (2015).

At each site, thirty-two $2 \times 2 \mathrm{~m}$ plots were established in areas where cover of the ground cover weed was close to $100 \%$ (the 'high weed' plots described in McAlpine et al. 2015). Plots were spaced at least $3 \mathrm{~m}$ apart, to allow for a 1 $\mathrm{m}$ buffer zone on all four sides of each plot. The aim was to place half of the plots in high light, and half in low light at each site. However, because most study sites were lowland forest remnants surrounded by either pasture or roads, plots with truly high light (i.e. with open canopy overhead) were difficult to find. Accordingly, percent canopy cover ranged across a continuum at each site. The 16 plots in each nominal light environment were then randomly allocated to one of four weed control treatments (see next section), with four replicate plots per treatment.

\section{Ground cover weed treatments}

Glasshouse trials were commissioned in 2011 to determine the lowest effective rate of herbicide that could be used to control the three ground cover weed species. In these trials, James \& Dowsett (2015) compared the speed, duration and extent of defoliation by selected herbicides when applied at quarter, half and full label-recommended application rates for general weed control using a knapsack sprayer. On this basis, James \& Dowsett (2015) recommended two herbicide treatments for our field experiment: herbicide at half the recommended application rate, hereafter called the 'reduced rate', and herbicide at the full recommended application rate, hereafter called the 'full rate'. Additionally, a manual removal (hand weeding) treatment was included to compare plant responses to a non-herbicide weed removal method. All treatments were applied in November 2011 during fine, 
calm weather. Treatments were applied to the $2 \times 2 \mathrm{~m}$ plots and to the $1 \mathrm{~m}$ buffer on all sides, giving a total area treated $4 \times 4 \mathrm{~m}$ per plot. Experimental control (non-treatment) plots were also included.

Herbicide treatments were applied in $750 \mathrm{~L}$ water per ha per $20 \mathrm{~cm}$ of weed height. However, as the weed canopy height varied between plots, the actual amount of herbicide mixture applied per plot was scaled per $20 \mathrm{~cm}$ of weed height according to the equation: $(750 \mathrm{~L} \times$ weed height $(\mathrm{cm}) / 20) \times($ plot area $\left.\left(\mathrm{m}^{2}\right) / 10000\right)$. For all three species, triclopyr (Grazon $\left.{ }^{\circledR}\right)$ was used at the rate of $3.6 \mathrm{~g}$ active ingredient (ai) $\mathrm{L}^{-1}$ for the full rate and $1.8 \mathrm{~g} \mathrm{ai} \mathrm{L}^{-1}$ for the reduced rate. Although the residual half-life of triclopyr in soil can be up to 107 days (Wilcock et al. 1991), it is thought likely to be less persistent in the high organic carbon environment of forest soils, particularly if applied at low rates (James et al. 1999; Bolan et al. 2011). Triclopyr alone was less effective on plectranthus in glasshouse trials, possibly due to the ciliate nature of plectranthus leaves (James \& Dowsett 2015), so diquat (Reglone ${ }^{\circledR}$ ) was also included in the tank mix at the rate of $0.6 \mathrm{~g}$ ai L $\mathrm{L}^{-1}$ and $0.3 \mathrm{~g}$ ai $\mathrm{L}^{-1}$ for full and reduced rates respectively. All herbicide treatments also included the adjuvant Pulse ${ }^{\circledR}$ Penetrant at $0.1 \%$ per volume of water. Treatments were applied using a $5 \mathrm{~L}$, hand-held pressurised sprayer distributing the herbicide over the top and within the canopy of the weed to maximise wetting of the weed foliage.

In the manual treatments, weed biomass was physically removed from each plot (and buffer zone) by hand. For tradescantia and plectranthus, care was taken to remove root material as thoroughly as possible, whilst minimising soil disturbance. This was more difficult with climbing asparagus, which typically had a dense mat of roots and underground tubers. A previous New Zealand study suggested that the ability of climbing asparagus to re-sprout was limited to the meristematic tissue that is just under the soil surface (Timmins \& Reid 2000), so manual removal was done only to that extent, using trowels. Unfortunately, it was later discovered that all tubers need to be removed in order to avoid re-sprouting.

\section{Vegetation measures}

Vegetation in plots was assessed according to the Landcare Research Recce method (Hurst \& Allen 2007). Pre-treatment assessments were done from June-September 2011. Treatments were applied in November 2011. Vegetation was then reassessed 2, 12, and 24 months post-treatment in January 2012, November 2012, and November 2013, respectively. Vegetation cover was visually assessed within the following height classes: $<0.1 \mathrm{~m}, 0.1-0.3 \mathrm{~m}, 0.3-1 \mathrm{~m}$. Species that had live leaves in any given height class were given a cover class score as follows: $<1 \%$ cover $=1,1-5 \%$ cover $=2,6-25 \%$ cover $=3,26-50 \%$ cover $=4,51-75 \%$ cover $=5,76-100 \%$ cover $=6$. Abundance scores for individual species in each plot were calculated by summing cover-class scores. For example, if a species had been scored 3 in the height class $0.1-0.3 \mathrm{~m}$ and 2 in the height class $<0.1 \mathrm{~m}$, it received an overall score of 5. Overall abundance per plot was calculated by summing the individual species' abundance scores. Species richness per plot was calculated by counting the number of species present. Measures of exotic abundance and species richness do not include the focal ground cover weed species (which was measured separately) at each site.

Ground cover weed volume in each plot was calculated by multiplying weed height by percent cover of the weed to give a measure of cubic metres of weed per $4 \mathrm{~m}^{2}$ plot. Weed height was usually reasonably uniform within each plot, but where this was not the case, maximum and minimum heights were averaged.

\section{Environmental measures}

Percent canopy openness above plots was used as an indicator of light availability, and was quantified using the HemiView Forest Canopy Analysis System v8 (Delta-T Devices, Cambridge, UK). Photographs of the forest canopy were taken from approximately $1 \mathrm{~m}$ above the middle of each plot using a Canon EOS 50D digital SLR camera and $4.5 \mathrm{~mm}$ Sigma EX DC hemispherical (fisheye) lens. Photographs were then digitally analysed using the HemiView image processing software.

\section{Statistical analysis}

The effects of weed treatment, canopy openness and site on the volume of each ground cover weed species at 24 months were modelled using linear models. For each weed species, the effects of weed treatment, canopy openness and site on the abundance and richness at 12 and 24 months of both native species and exotic species (other than the focal ground cover weed) were also modelled. Canopy openness was mean-centred and divided by one standard deviation so that all predictors were on a common scale (Gelman \& Hill 2007). All analyses were conducted using R 3.3.1 (R Core Team 2016).

For native and exotic species, generalised linear models (GLMs) with a Poisson distribution were fitted. The dispersion statistic for the Poisson model (Zuur \& Ieno 2016) was calculated, and where this exceeded the expected range based on 10000 Poisson datasets simulated from the fitted model, a negative binomial GLM was fitted using the MASS package (Venables \& Ripley 2002).

Where the data had a high proportion of zeros, the pscl package (Jackman 2015) was used to fit a hurdle model (Zeileis et al. 2008). Hurdle models (also called zero-adjusted Poisson models; Zuur \& Ieno 2016) are two component models that allow for excess zeros (those not explained by covariates), which the Poisson distribution cannot handle (Zeileis et al. 2008; Zuur \& Ieno 2016). A hurdle model was specified with a binomial component to model absence/presence data (zero or not), and a Poisson component for abundance or species richness when present (positive counts). Hurdle models contained all three covariates in both the count and binary parts of the model.

Poisson, negative binomial and hurdle models were compared using Akaike's Information Criterion (AIC), and the model with the lowest AIC value was selected as the final model. Goodness-of-fit was evaluated for final Poisson and negative binomial models to determine their explanatory ability (Mac Nally et al. 2018) using generalised $\mathrm{R}^{2}$ calculated after Zuur \& Ieno (2016): Generalised $\mathrm{R}^{2}=$ (null deviance - residual deviance)/null deviance. Generalised $\mathrm{R}^{2}$ is a measure of the variance explained compared to the null (intercept only) model. Model coefficients were plotted using ggplot2 (Wickham 2009) based on R code by Sparks (2012).

\section{Results}

\section{Ground cover weed volume}

Manual removal, full herbicide and reduced herbicide application all significantly reduced the volume of climbing asparagus (manual removal, $\mathrm{P}=0.028$; full herbicide, $\mathrm{P}=$ 
0.032; reduced herbicide, $\mathrm{P}=0.003$ ), plectranthus (manual, $\mathrm{P}<0.001$; full, $\mathrm{P}<0.001$; reduced, $\mathrm{P}<0.001$ ) and tradescantia (manual, $\mathrm{P}<0.001$; full, $\mathrm{P}=0.046$; reduced, $\mathrm{P}=0.001$ ) after 24 months compared to untreated plots (Fig. 1). However, although there was a large reduction in the volume of all three ground cover weed species two months after treatment, the long-term effect of weed treatments on weed volume was small for climbing asparagus and tradescantia (Fig. 2). 24 months after treatment, climbing asparagus had almost recovered to pre-treatment volumes (Fig. 2).

For climbing asparagus and tradescantia, canopy openness was significantly positively correlated with weed volume after 24 months ( $\mathrm{P}=0.004$ and $\mathrm{P}<0.001$, respectively), but there was no relationship for plectranthus ( $\mathrm{P}=0.298$; Figs. 1 and 3$)$. Where canopy openness was greater than c. $12 \%$, tradescantia recovered to pre-treatment levels within 24 months (Fig. 3). The adjusted $\mathrm{R}^{2}$ values for the models were: climbing asparagus $=$ 0.261 , plectranthus $=0.56$, tradescantia $=0.416$.

\section{Native and exotic plant abundance and species richness}

For all three weed species, results at 12 months were very similar to those at 24 months, so only the results for 24 months are reported. At sites invaded by climbing asparagus, none of the weed treatments had a significant effect on native plant abundance or species richness after 24 months (Table 1; Figs. 4 and 5). At sites invaded by plectranthus and tradescantia, manual removal increased native abundance and species richness compared to untreated plots (Table 1; Figs. 4 and 5). Manual removal also increased the abundance and richness of exotic species at sites invaded by asparagus and plectranthus, and the richness of exotic species when present at sites invaded by tradescantia (Table 1; Figs. 4 and 5).
Herbicide treatments had almost no effect on the abundance and richness of native species (Table 1; Figs. 4 and 5). The only exception was at sites invaded by plectranthus, where reduced herbicide increased native species richness compared to untreated plots. Both full and reduced herbicide treatments increased exotic abundance and species richness at sites invaded by plectranthus, and exotic species richness at sites invaded by asparagus, compared to untreated plots.

At sites invaded by tradescantia, other exotic plant species were absent from $75 \%$ of plots. The zero components of exotic abundance and exotic species richness models both modelled the presence of exotic species. Therefore, results for the two were identical and are presented together. None of the weed treatments had a significant effect on the likelihood of exotic species being present (zero component of both abundance and richness models; manual removal, estimate $=2.897$, $\mathrm{SE}=1.522$; full herbicide, estimate $=-2.891, \mathrm{SE}=2.479$; reduced herbicide, estimate $=-2.997, \mathrm{SE}=2.641$; Table 1).

Canopy openness was significantly negatively correlated with native abundance at sites invaded by tradescantia and with native species richness at all sites (Table 1; Fig. 5). Canopy openness was significantly positively correlated with the presence (tradescantia), abundance and richness of exotic species across all sites. At sites invaded by tradescantia, exotic plant species were absent from plots between 5-8\% canopy openness.

In general, most life-forms of both native and exotic species increased in frequency (the number of times recorded in plots) 24 months after treatment (Table 2). However, the highest increases were for exotic annual herbs (1467\%), exotic perennial herbs (303\%), and exotic trees and shrubs $(173 \%)$ (Table 2). Native tree and shrub species that were

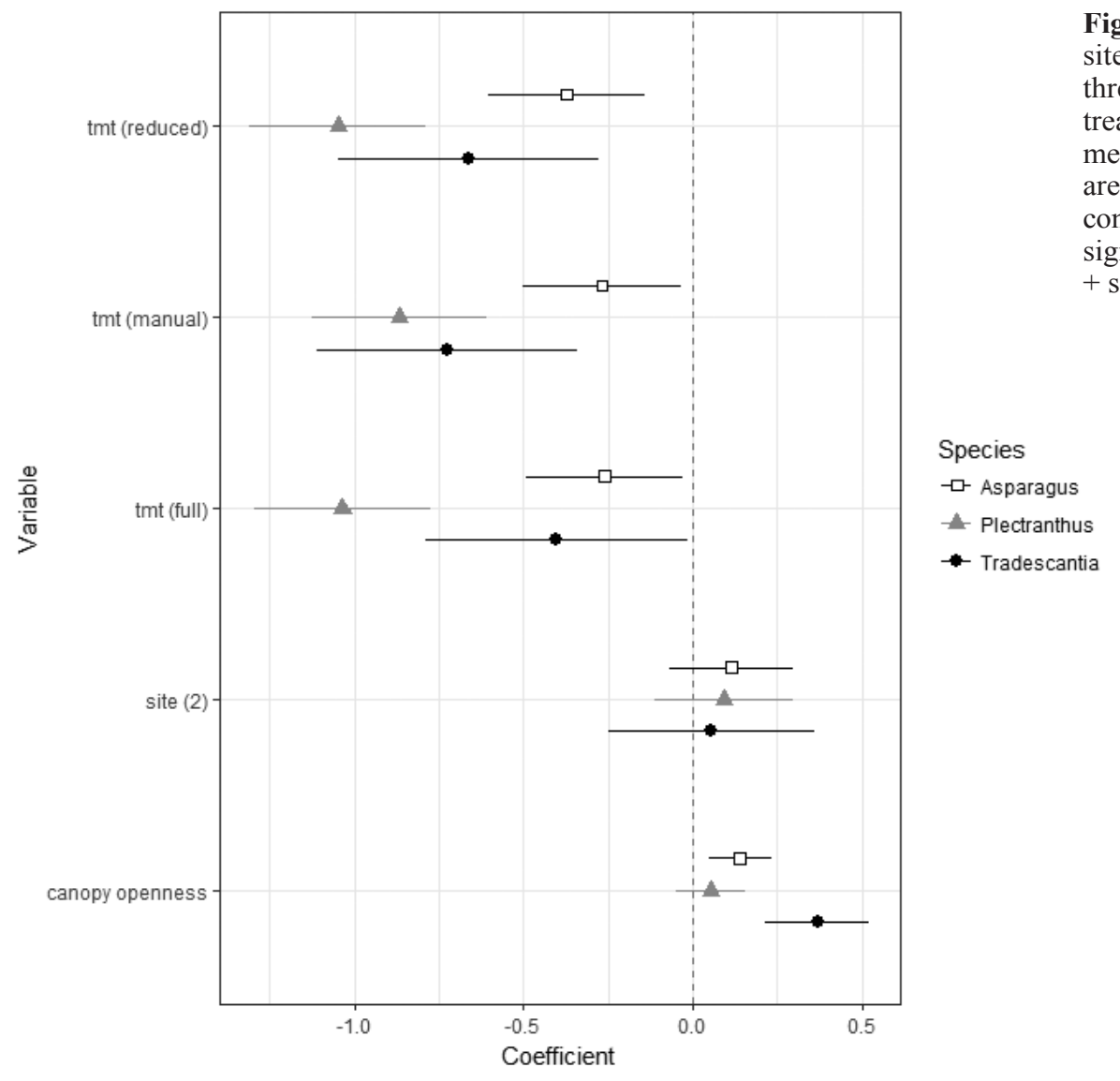

Figure 1. Estimated effects of weed treatments, site and canopy openness on volume $\left(\mathrm{m}^{3}\right)$ of three ground cover weed species 24 months after treatments were applied. Points represent the mean estimates for weed volume and error bars are $95 \%$ confidence intervals. Where the $95 \%$ confidence interval excludes zero, predictors differ significantly from the intercept model (untreated + site $=1+$ mean value for canopy openness).

\footnotetext{
Species

- Asparagus

- Plectranthus

- Tradescantia
} 

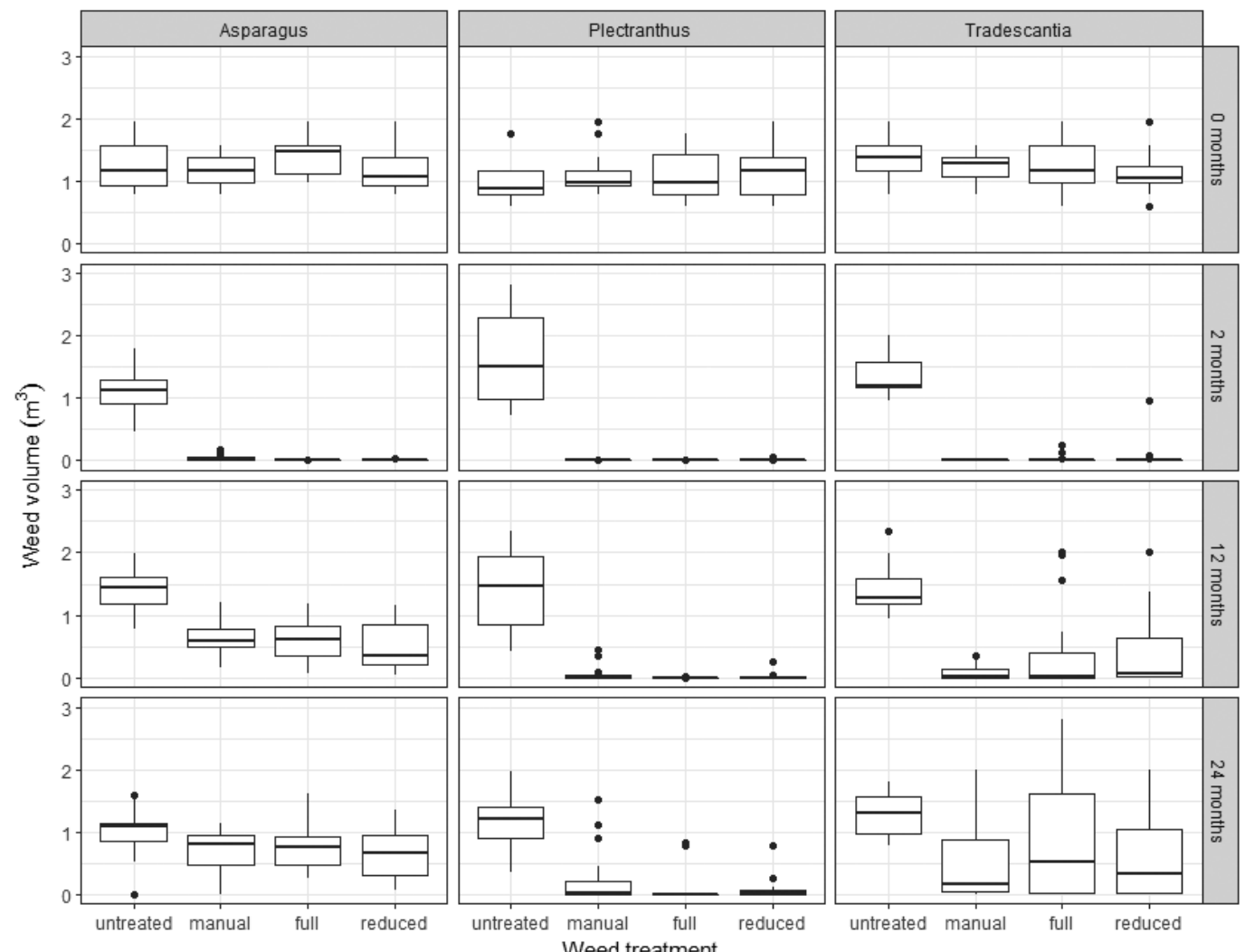

Figure 2. Effect of weed treatment on volume $\left(\mathrm{m}^{3}\right)$ of three ground cover weed species at $0,2,12$ and 24 months after treatments were applied. "Untreated" = untreated control, "manual" $=$ manual removal, "full" = herbicide applied at full rate, "reduced"=herbicideapplied at reduced rate. Boxplots display median (solid horizontal bar), $25^{\text {th }}$ and $75^{\text {th }}$ percentiles (upper and lower horizontal bars), smallest value $\geq 25^{\text {th }}$ percentile $1.5 \times$ inter-quartile range (lower whisker), largest value $\leq 75^{\text {th }}$ percentile + $1.5 \times$ inter-quartile range (upper whisker), and outliers (points).
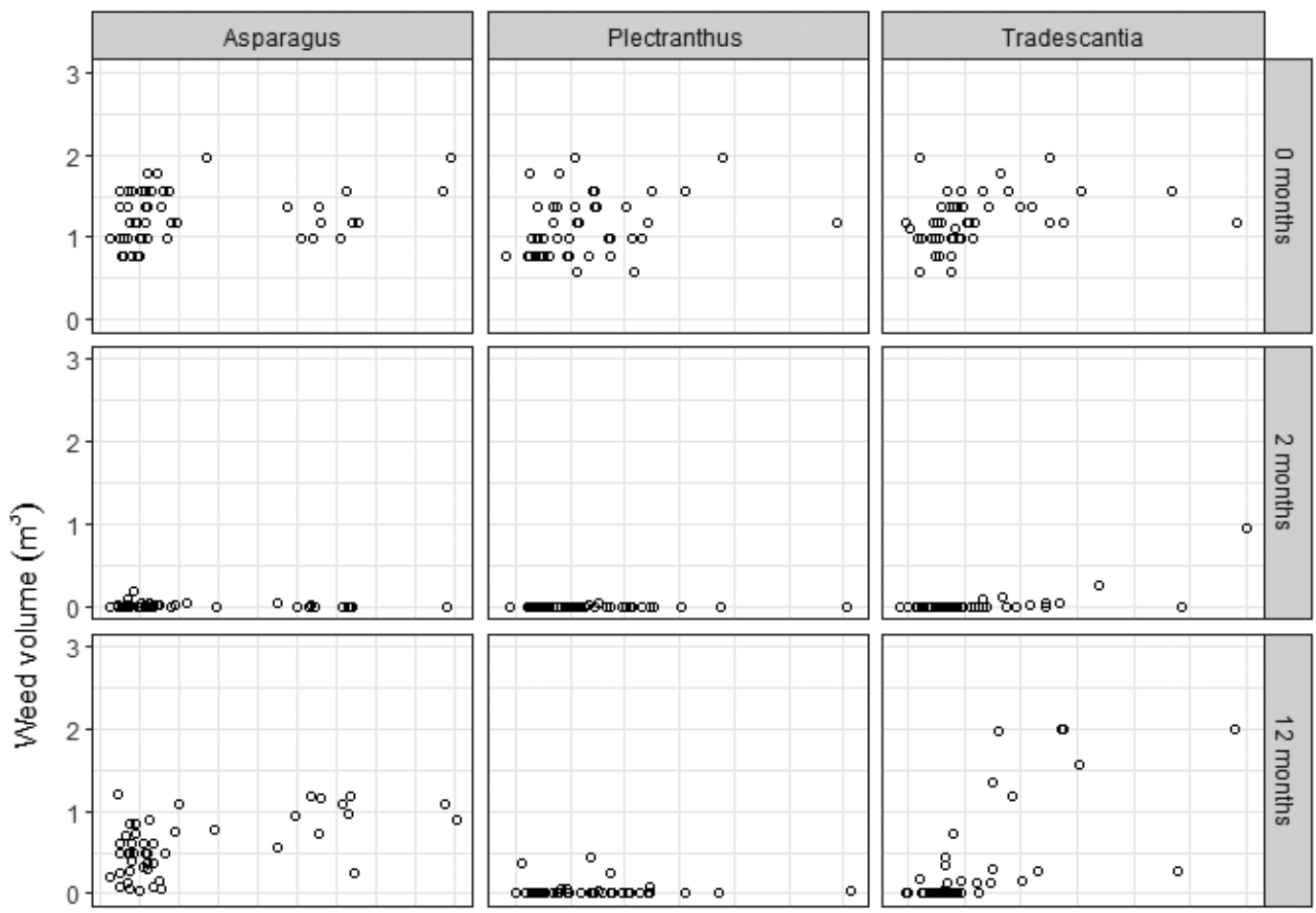

Figure 3. Relationship between canopy openness and weed volume $\left(\mathrm{m}^{3}\right)$ for three ground cover weed species for treated plots (manual removal, full herbicide and reduced herbicide) at 0,2,12 and 24 months after weed treatment. Points are jittered to reduce overlap.
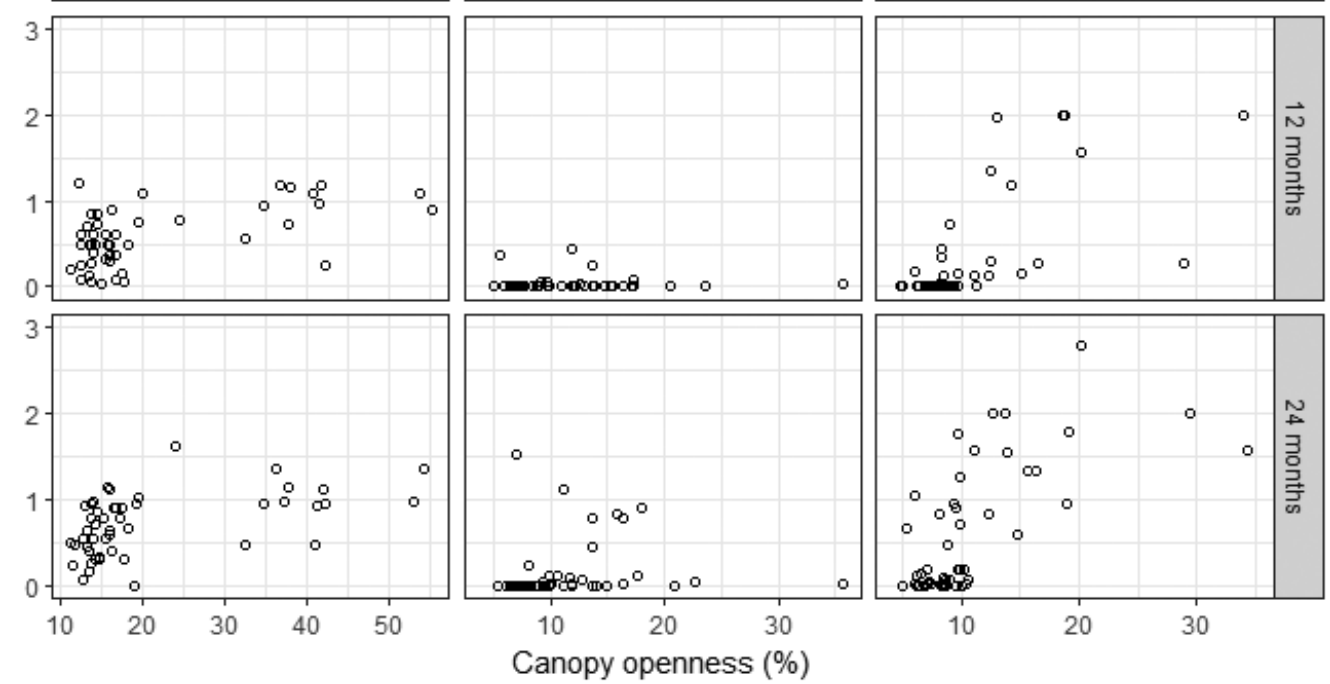

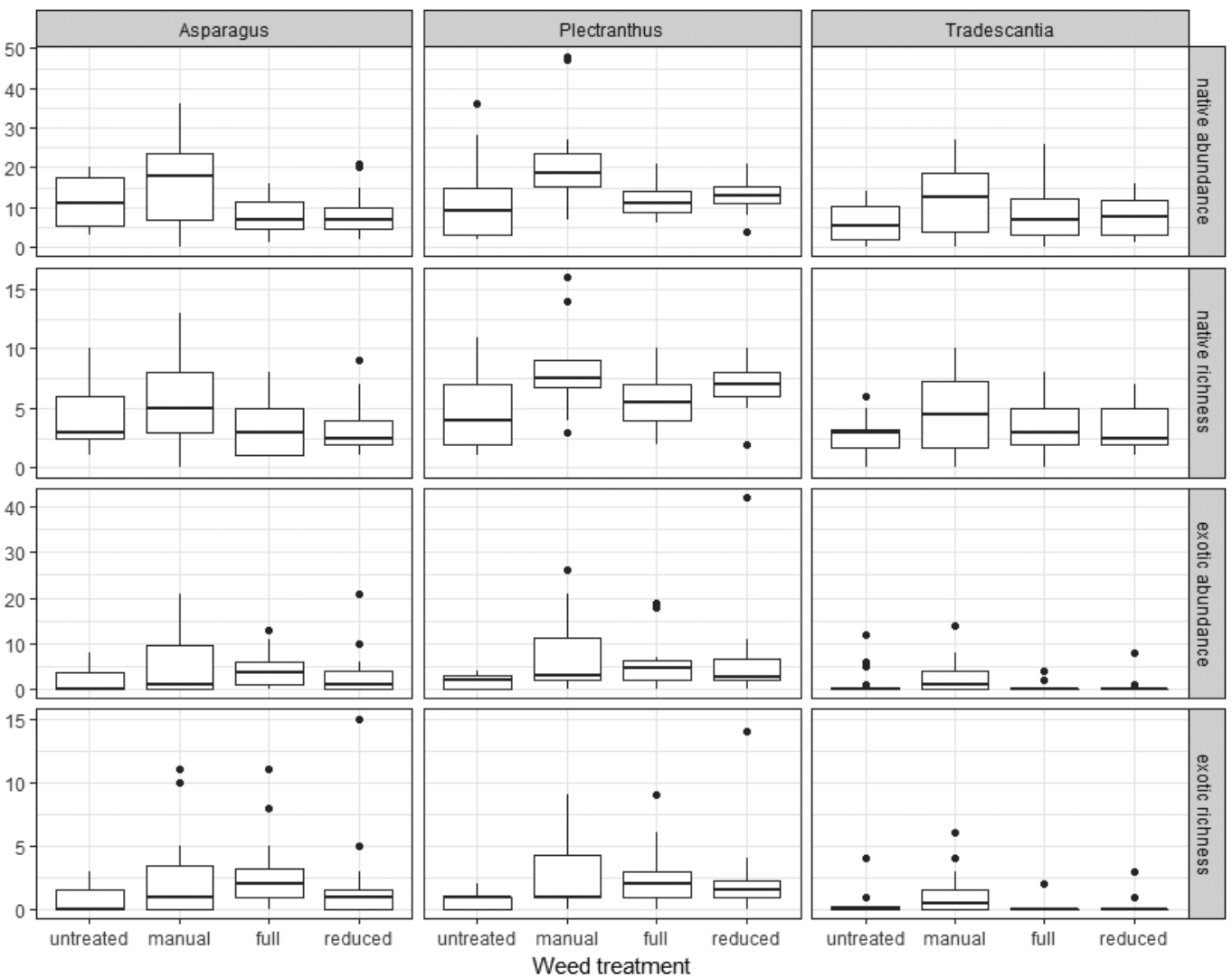

Figure 4. Effect of weed treatments on abundance (based on percent cover scores, see Methods for details) and species richness of native and exotic plants in experimental plots at sites invaded by climbing asparagus, plectranthus or tradescantia 24 months after treatments were applied. See Figure 2 for explanation of symbols.
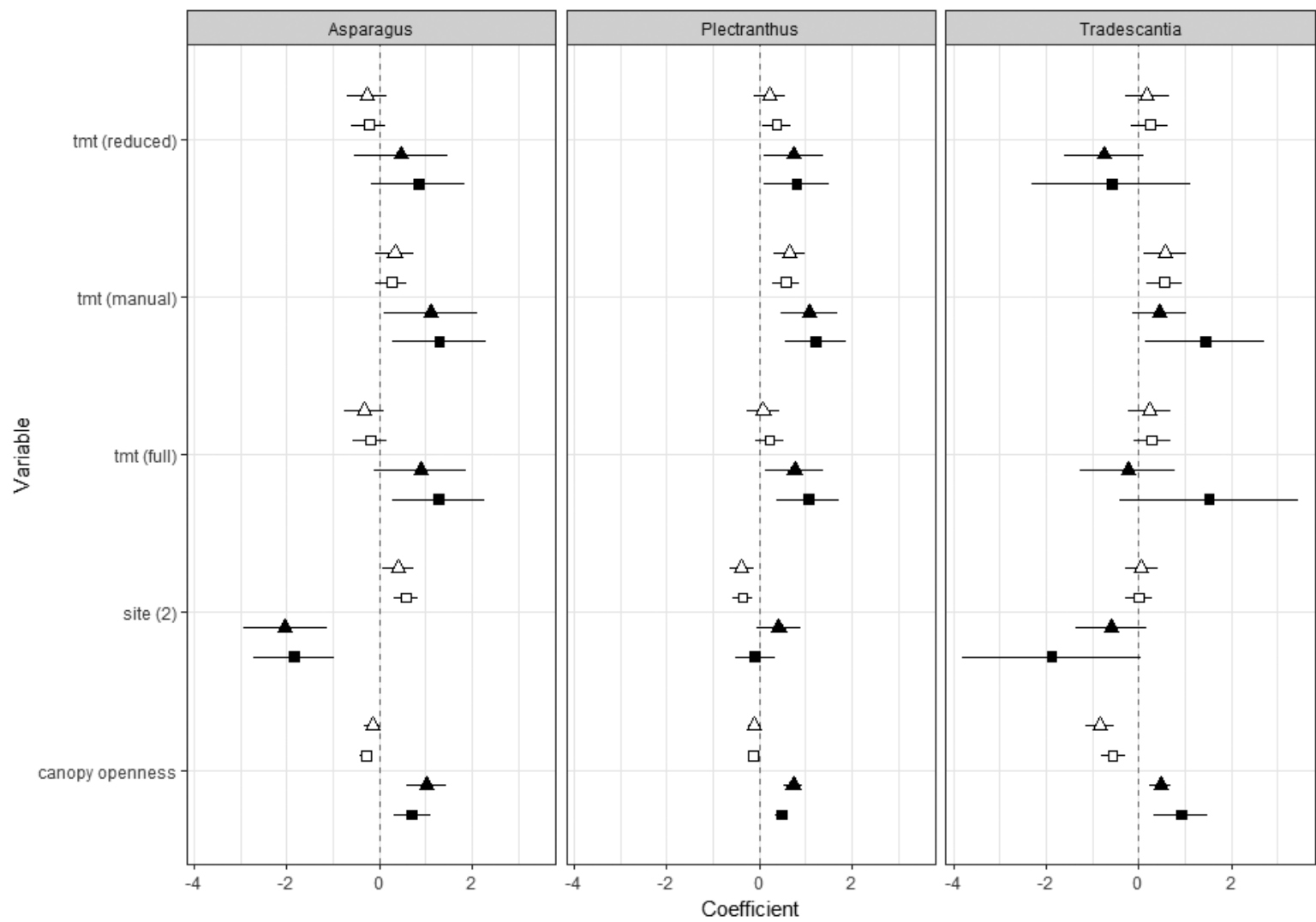

Response

$\triangle$ Native abundance

$\neg$ - Native richness

- Exotic abundance

- Exotic richness

Figure 5. Estimated effects of weed treatments, site and canopy openness on mean native and exotic abundance (based on percent cover scores, see Methods for details) and species richness at sites invaded by ground cover weeds, 24 months after treatments were applied. For tradescantia, estimates are for abundance when present and species richness when present. Estimates for tradescantia presence are reported in the text. Points represent mean estimates and error bars are 95\% confidence intervals. Where the $95 \%$ confidence interval (error bar) excludes zero, predictors differ significantly from the intercept model (untreated + site $=1+$ mean value for canopy openness). 
Table 1. Effects of weed treatments (manual removal, full herbicide and reduced herbicide) and canopy openness on the abundance and richness of native and exotic species at sites invaded by ground cover weeds 24 months after treatments were applied. Results are for the best-supported model given the data. *indicates statistically significant effect $(\mathrm{P}<0.05)$.

\begin{tabular}{|c|c|c|c|c|c|c|c|}
\hline \multirow[t]{2}{*}{ Weed } & \multirow[t]{2}{*}{ Response } & \multirow[t]{2}{*}{ Best model } & \multirow[t]{2}{*}{$\mathbf{R}^{2}$} & \multicolumn{4}{|c|}{$\mathbf{P}$} \\
\hline & & & & $\begin{array}{l}\text { manual } \\
\text { removal }\end{array}$ & $\begin{array}{c}\text { full } \\
\text { herbicide }\end{array}$ & $\begin{array}{c}\text { reduced } \\
\text { herbicide }\end{array}$ & $\begin{array}{c}\text { canopy } \\
\text { openness }\end{array}$ \\
\hline \multirow[t]{4}{*}{ Climbing asparagus } & Native abundance & Negative binomial & 0.235 & 0.119 & 0.146 & 0.227 & 0.072 \\
\hline & Native richness & Poisson & 0.333 & 0.12 & 0.289 & 0.231 & $<0.001 *$ \\
\hline & Exotic abundance & Negative binomial & 0.311 & $0.033 *$ & 0.081 & 0.368 & $<0.001^{*}$ \\
\hline & Exotic richness & Negative binomial & 0.304 & $0.012 *$ & $0.011 *$ & 0.103 & $<0.001 *$ \\
\hline \multirow[t]{4}{*}{ Plectranthus } & Native abundance & Negative binomial & 0.286 & $<0.001^{*}$ & 0.622 & 0.204 & 0.163 \\
\hline & Native richness & Poisson & 0.278 & $<0.001^{*}$ & 0.154 & $0.011 *$ & $0.037 *$ \\
\hline & Exotic abundance & Negative binomial & 0.515 & $<0.001^{*}$ & $0.017 *$ & $0.023 *$ & $<0.001^{*}$ \\
\hline & Exotic richness & Poisson & 0.615 & $<0.001 *$ & $0.002 *$ & $0.025^{*}$ & $<0.001 *$ \\
\hline \multirow[t]{5}{*}{ Tradescantia } & Native abundance & Negative binomial & 0.422 & $0.015^{*}$ & 0.32 & 0.463 & $<0.001 *$ \\
\hline & Native richness & Poisson & 0.368 & $0.004 *$ & 0.167 & 0.256 & $<0.001 *$ \\
\hline & Exotic presence $^{\mathrm{a}}$ & Zero-adjusted Poisson & - & 0.057 & 0.244 & 0.256 & $0.004 *$ \\
\hline & Exotic abundance & Zero-adjusted Poisson & - & 0.133 & 0.648 & 0.083 & $<0.001^{*}$ \\
\hline & Exotic richness & Zero-adjusted Poisson & - & $0.029 *$ & 0.125 & 0.502 & $0.002 *$ \\
\hline
\end{tabular}

${ }^{\mathrm{a}}$ zero-component of both exotic abundance and exotic species richness models.

Table 2. Total number of native and exotic species, classified by life-form, recorded in 144 treatment plots (across 6 sites) prior to, and 24 months after, application of manual and herbicide weed control treatments.

\begin{tabular}{lcccccc}
\hline & \multicolumn{3}{c}{ Native } & \multicolumn{2}{c}{ Exotic } \\
\cline { 2 - 7 } & Pre-treatment & $\mathbf{2 4}$ months & \% change & Pre-treatment & 24 months & \% change \\
\hline Trees \& shrubs & 487 & 644 & 32 & 37 & 101 & 173 \\
Ferns & 116 & 165 & 42 & 0 & 0 & - \\
Vines & 47 & 68 & 45 & 12 & 19 & 58 \\
Perennial herbs & 5 & 11 & 120 & 29 & 117 & 303 \\
Annual herbs & 0 & 0 & - & 14 & 47 & 1467 \\
Grasses & 28 & 63 & 125 & 0 & 2 & 36 \\
Sedges & 18 & 20 & 11 & -33 \\
Orchids & 0 & 2 & - & 0 & -
\end{tabular}

most common before treatment were generally also the most common species 24 months after treatment (Table 3 ). This was also largely true for exotic tree and shrub species, except for Berberis glaucocarpa, which was absent prior to treatment, but was present in eleven plots 24 months after treatment (Table 3). Prunus spp. (cherry) also increased from being recorded in five plots before treatment, to 23 plots 24 months after treatment (Table 3 ).

\section{Discussion}

Environmental weed control methods that remove the weed whilst also minimising damage to resident native species are likely to result in the best ecological outcomes (Mason \& French 2007; Skurski et al. 2013). This study demonstrates that it may be possible to achieve this by using a reduced rate of herbicide for weed control; at plectranthus sites, the lower rate of herbicide effectively controlled plectranthus and resulted in a better outcome for native plant species richness compared to the full rate. Additionally, although only plectranthus was successfully controlled in the long term, the reduced rate of herbicide gave a similar level of control as the full rate of herbicide for all three ground cover weed species. This suggests that further research into the efficacy of lower herbicide application rates on environmental weeds would be valuable.

For tradescantia and climbing asparagus, native plant communities did not benefit from either herbicide treatment, likely due to the recovery of the weeds. Although glasshouse trials had indicated that successful control of tradescantia and climbing asparagus could be achieved at both full and reduced rates of herbicide (James \& Dowsett 2015), these results did not translate to the field experiment. This may have been because the glasshouse trials were conducted on potted plants, which are likely easier to kill, given their smaller size and lack of below-ground energy stores. Additionally, tradescantia can regenerate from tiny stem fragments (Kelly 
Table 3. Native and exotic tree and shrub species/genera prior to, and 24 months after, application of manual and herbicide weed control treatments. All exotic and the 10 most common native tree and shrub species/genera recorded in the 144 treatment plots (across 6 sites) are listed, with number of plots in brackets.

\section{TREES \& SHRUBS}

Native

\section{Exotic}

\begin{tabular}{llll}
\hline Pre-treatment & 24 months & Pre-treatment & 24 months \\
\hline Piper excelsum (87) & Piper excelsum (120) & Ligustrum spp. (10) & Prunus spp. (23) \\
Melicytus ramiflorus (71) & Melicytus ramiflorus (89) & Solanum mauritianum (10) & Solanum mauritianum (12) \\
Knightia excelsa (52) & Hedycarya arborea (73) & Paraserianthes lophantha (6) & Paraserianthes lophantha (19) \\
Hedycarya arborea (51) & Geniostoma ligustrifolium (59) & Prunus spp. (5) & Ligustrum spp. (18) \\
Geniostoma ligustrifolium (47) & Knightia excelsa (56) & Cotoneaster spp. (3) & Berberis glaucocarpa (11) \\
Cyathea dealbata (26) & Myrsine australis (36) & Rubus fruiticosus agg. (1) & Pinus spp. (5) \\
Myrsine australis (25) & Dysoxylum spectabile (32) & & Dendrobenthamia capitata (4) \\
Alectryon excelsus (20) & Cyathea dealbata (30) & & Ulex europaeus (3) \\
Dysoxylum spectabile (22) & Aristotelia serrata (28) & & Cotoneaster spp. (2) \\
Coprosma grandifolia (14) & Alectryon excelsus (16) & & Acacia mearnsii (1) \\
& & & Rubus fruiticosus agg. (1)
\end{tabular}

\& Skipworth 1984a), and climbing asparagus can re-sprout from underground tubers so it is likely that our control methods were not sufficient to completely kill all live plant material for these species. Repeat applications of herbicide are obviously required for sustained control of these weed species, as studies have previously shown for tradescantia (e.g. Standish 2002; Hurrell et al. 2012; Lusk et al. 2012). Results from the current study suggest that follow-up control of tradescantia and climbing asparagus should be done within one year of initial control, whereas follow-up control of plectranthus may not be necessary for two years or more after initial control.

Manual removal of plectranthus and tradescantia resulted in the greatest benefits for native plant abundance and species richness, likely because of the reduced risk of non-target damage. However, manual control is not usually a feasible control method, except over very small areas. Additionally, manual removal also increased exotic plant abundance and/or species richness for all three weed species, and the herbicide treatments had the same effect for plectranthus (at both the full and reduced rates) and climbing asparagus (at the full rate only). Many other studies have demonstrated that the removal of one weed species can facilitate the establishment of other weed species, likely due to the decrease in competition and increase in resource availability resulting from weed removal (Kettenring \& Adams 2001; Buckley et al. 2007; Rinella et al. 2009). This secondary invasion of other exotic species has been described as a 'formidable barrier' to the conservation of natural areas threatened by weeds (Pearson et al. 2016), and highlights why weed removal in isolation can be counterproductive to restoration goals. In the current study, exotic annual and perennial herbs had the highest increase in occurrence following weed control. Annual herbs tend to have minor, short-lived impacts where they invade, but perennial herbs such as tradescantia and wild ginger (Hedychium species) can have serious impacts on native plants, animals and ecosystems (Standish et al. 2001; Williams et al. 2003; Standish 2004; Bassett 2014; McAlpine et al. 2015). Exotic tree and shrub species can also have long-term negative impacts on natural ecosystems (Lowe et al. 2001; Richardson \& Rejmánek 2011), so the invasion of Berberis glaucocarpa and Prunus spp. following weed control in the current study is concerning.

Results from the current study also show that light environment can influence recovery of both the target weed and the resident plant community following weed control. Post-control recovery of tradescantia and climbing asparagus was positively correlated with high light, which aligns with previous studies (Kelly \& Skipworth 1984a; Maule et al. 1995; Standish et al. 2001; McAlpine et al. 2015). Additionally, native plant richness at all sites, and native plant abundance at tradescantia sites decreased with increasing canopy openness. This may have been due to the natives being unable to compete with the high levels of weed volume achieved in high light. Standish (2002) also demonstrated that tradescantia re-growth following control was positively related to light availability, and negatively related to native forest regeneration. In the current study, abundance and richness of other exotic species also generally increased with increasing canopy openness, indicating that invasion of exotic species following ground cover weed control is most likely in high light areas such as on forest edges or in canopy gaps. These results indicate that achieving ecological benefits from weed control in high light areas may be more difficult than in low light areas, and thus may require a different management approach. For example, faster and more aggressive follow-up control of both the target weed and other exotic plant species may be necessary in high light areas. Creating shade by planting with fast-growing native species might also slow weed recovery and/or re-invasion (Kelly \& Skipworth 1984a; Standish et al. 2001).

This study has demonstrated that plectranthus can be successfully controlled using a reduced rate of herbicide, and that this lower rate can be beneficial for native plants. Further research to fine-tune these results and extend them to other ground cover weed species would be invaluable.

\section{Acknowledgements}

This project was funded by the Ministry of Business, Innovation and Employment through Landcare Research's Core Funded programme Beating Weeds II, and the New Zealand Department of Conservation. Trevor James (AgResearch) provided 
herbicide advice following glasshouse trials. Thanks to Ian Nobel, Tim \& Heather Ryan, Ed \& Sue Harvey, Keith \& Denize Anderton, Chris Clark (Department of Conservation), Kerry Watson (Trustpower), and Greg Shaw (South Waikato District Council) for site access, and to Graeme Bourdôt, Tom Belton, Sarah Crump, Simon Fowler, Sarah Jackman, Kris Kramer-Walter, Carrie Lusk, Brodi Muschamp, Walter Stahel, Mike Trolove, and Nancy van Nieuwenhove for other assistance. Comments from Clayson Howell, Tim Curran and two anonymous referees improved the manuscript.

\section{References}

Bassett I 2014. Impacts on invertebrate fungivores: a predictable consequence of ground-cover weed invasion? Biodiversity and Conservation 23: 791-810.

Blackshaw RE, O’Donovan JT, Harker K, Clayton GW, Stougaard RN 2006. Reduced herbicide doses in field crops: a review. Weed Biology and Management 6: 10-17.

Bolan NS, Adriano DC, KunhikrishnanA, James T, McDowell R, Senesi N2011. Dissolved organic matter: biogeochemistry, dynamics, and environmental significance in soils. Advances in Agronomy 110: 1-78.

Buckley YM, Bolker BM, Rees M 2007. Disturbance, invasion and re-invasion: managing the weed-shaped hole in disturbed ecosystems. Ecology Letters 10: 809-817.

Cabin RJ, Weller SG, Lorence DH, Cordell S, Hadway LJ 2002a. Effects of microsite, water, weeding, and direct seeding on the regeneration of native and alien species within a Hawaiian dry forest preserve. Biological Conservation 104: 181-190.

Cabin RJ, Weller SG, Lorence DH, Cordell S, Hadway LJ, Montgomery R, Goo D, Urakami A 2002b. Effects of light, alien grass, and native species additions on Hawaiian dry forestrestoration. Ecological Applications 12: 1595-1610.

D'Antonio C, Meyerson LA 2002. Exotic plant species as problems and solutions in ecological restoration: a synthesis. Restoration Ecology 10: 703-713.

D’Antonio CM, Hughes RF, Mack M, Hitchcock D, Vitousek PM 1998. The response of native species to removal of invasive exotic grasses in a seasonally dry Hawaiian woodland. Journal of Vegetation Science 9: 699-712.

Endress BA, Parks CG, Naylor BJ, Radosevich SR 2008. Herbicide and native grass seeding effects on sulfur cinquefoil (Potentilla recta)-infested grasslands. Invasive Plant Science and Management 1: 50-58.

Falk-Petersen J, Bøhn T, Sandlund OT 2006. On the numerous concepts in invasion biology. Biological Invasions 8: 1409-1424.

Flory SL 2010. Management of Microstegium vimineum invasions and recovery of resident plant communities. Restoration Ecology 18: 103-112.

Gelman A, Hill J 2007. Data analysis using regression and multilevel/hierarchical models. Cambridge, Cambridge University Press. 651 p.

Hansen MJ, Wilson SD 2006. Is management of an invasive grass Agropyron cristatum contingent on environmental variation? Journal of Applied Ecology 43: 269-280.

Harrington K, Schmitz H 2007. Initial screening of herbicides tolerated by native plants. New Zealand Plant Protection 60: $133-136$

Howell CJ, Terry JA2016. The creation of a New Zealand weed atlas. Science for Conservation Series 328. Wellington,
Department of Conservation. $21 \mathrm{p}$.

Hurrell G, James T, Lusk C, Trolove M2008. Herbicide selection for wandering jew (Tradescantia fluminensis) control. New Zealand Plant Protection 61: 368-373.

Hurrell G, James T, Lamoureaux S, Lusk C, Trolove M 2009. Effects of rate of application of Triclopyr on wandering jew (Tradescantia fluminensis Vell.). New Zealand Plant Protection 62: 363-367.

Hurrell GA, Belton T, Lusk CS, Lamoureaux SL 2012. Tradescantia management in a New Zealand National Park. Ecological Management \& Restoration 13:311-314.

Hurst JM, Allen RB 2007. The recce method for describing New Zealand vegetation - expanded manual. Landcare Research Contract Report: LC0708/029. Lincoln, Landcare Research. 64 p.

Jackman SD 2015. pscl: Classes and Methods for R Developed in the Political Science Computational Laboratory, Stanford University. Stanford, California. R package version 1.4.9.

James TK, Dowsett CA 2015. Herbicide responses of matforming weeds of forest remnants in New Zealand. New Zealand Plant Protection 68: 1-6.

James TK, Holland PT, RahmanA, Lu YR 1999. Degradation of the sulfonylurea herbicides chlorsulfuron and triasulfuron in a high-organic-matter volcanic soil. Weed Research 39: 137-148.

Katagi T 2004. Photodegradation of pesticides on plant and soil surfaces. Reviews of environmental contamination and toxicology 182: 1-77.

Kelly D, Skipworth JP 1984a. Tradescantia fluminensis in a Manawatu (New Zealand) forest: I. Growth and effects on regeneration. New Zealand Journal of Botany 22:393-397.

Kelly D, Skipworth JP 1984b. Tradescantia fluminensis in a Manawatu (New Zealand) forest: II. Management by herbicides. New Zealand Journal of Botany 22: 399-402.

Kettenring KM,Adams CR 2001. Lessons learned from invasive plant control experiments: a systematic review and metaanalysis. Journal of Applied Ecology 48: 970-979.

Kudsk P 2008. Optimising herbicide dose: a straightforward approach to reduce the risk of side effects of herbicides. The Environmentalist 28: 49-55.

Kuebbing SE, Nuñez MA2015. Negative, neutral, and positive interactions among nonnative plants: patterns, processes, and management implications. Global Change Biology 21: 926-934.

Loh RK, Daehler CC 2008. Influence of woody invader control methods and seed availability on native and invasive species establishment in a Hawaiian forest. Biological Invasions 10: 805-819.

Lowe S, Browne M, Boudjelas S, De Poorter M 2001. 100 of the world's worst invasive alien species: a selection from the global invasive species database. Auckland, Invasive Species Specialist Group (ISSG) a specialist group of the Species Survival Commission (SSC) of the World Conservation Union (IUCN). $12 \mathrm{p}$.

Lusk C, Hurrell G, Lamoureaux S 2012. Native plant and weed diversity in forest remnants affected by Tradescantia fluminensis management. New Zealand Plant Protection 65: 74-80.

Mac Nally R, Duncan RP, Thomson JR, Yen JD 2018. Model selection using information criteria, but is the "best" model any good? Journal of Applied Ecology 5: 1411-1444.

Manalil S, Busi R, Renton M, Powles SB 2011. Rapid evolution of herbicide resistance by low herbicide dosages. Weed Science 59: 210-217. 
Mason TJ, French K 2007. Management regimes for a plant invader differentially impact resident communities. Biological Conservation 136: 246-259.

Matarczyk JA, Willis AJ, Vranjic JA, Ash JE2002. Herbicides, weeds and endangered species: management of bitou bush (Chrysanthemoides monilifera ssp. rotundata) with glyphosate and impacts on the endangered shrub, Pimelea spicata. Biological Conservation 108: 133-141.

Maule HG, Andrews M, Morton JD, Jones AV, Daly GT 1995. Sun/shade acclimation and nitrogen nutrition of Tradescantia fluminensis, a problem weed in New Zealand native forest remnants. New Zealand Journal of Ecology 19: 35-46.

McAlpine KG, Lamoureaux SL, Westbrooke I2015. Ecological impacts of ground cover weeds in New Zealand lowland forests. New Zealand Journal of Ecology 39: 50-60.

McAlpine KG, Lamoureaux SL, Timmins SM, Wotton DM 2017. Native woody plant recruitment in lowland forests invaded by ground cover weeds and non-native mammals. New Zealand Journal of Ecology 41: 65-73.

Neve P, Powles S 2005. High survival frequencies at low herbicide use rates in populations of Lolium rigidum result in rapid evolution of herbicide resistance. Heredity 95: 485-492.

Pearson DE, Ortega YK, Runyon JB, Butler JL 2016. Secondary invasion: the bane of weed management. Biological Invasions 197: 8-17.

R Core Team 2016. R: A language and environment for statistical computing. R Foundation for Statistical Computing, Vienna, Austria. Richardson DM, Rejmánek M 2011. Trees and shrubs as invasive alien species - a global review. Diversity and Distributions 17: 788-809.

Rinella MJ, Maxwell BD, Fay PK, Weaver T, Sheley RL 2009. Control effort exacerbates invasive-species problem. Ecological Applications 19: 155-162.

Sheley R, Denny MK 2006. Community response of nontarget species to herbicide application and removal of the nonindigenous invader Potentilla recta $\mathrm{L}$. Western North American Naturalist 66: 55-63.

Received 26 June 2017; accepted 28 May 2018

Editorial board member: Tim Curran
Skurski TC, Maxwell BD, Rew LJ 2013. Ecological tradeoffs in non-native plant management. Biological Conservation 159: 292-302.

Sparks D 2012. .A coefficient plot for multiple models. URL https://gist.github.com/dsparks/4332698 (accessed December 2016).

Standish RJ 2002. Experimenting with methods to control Tradescantia fluminensis, an invasive weed of native forest remnants in New Zealand. New Zealand Journal of Ecology 26: 161-170.

Standish RJ 2004. Impact of an invasive clonal herb on epigaeic invertebrates in forest remnants in New Zealand. Biological Conservation 116: 49-58.

Standish RJ, Robertson AW, Williams PA 2001. The impact of an invasive weed Tradescantia fluminensis on native forest regeneration. Journal of Applied Ecology 38: 1253-1263.

Thaxton JM, Cordell S, Cabin RJ, Sandquist DR 2012. Nonnative grass removal and shade increase soil moisture and seedling performance during Hawaiian dry forest restoration. Restoration Ecology 20: 475-482.

Timmins SM, Reid V 2000. Climbing asparagus, Asparagus scandens Thunb.: a South African in your forest patch. Austral Ecology 25: 533-538.

Venables WN, Ripley BD 2002. Modern applied statistics with S. 4th edn. New York, Springer-Verlag. 109 p.

Wickham H 2009. ggplot2: elegant graphics for data analysis. New York, Springer-Verlag. 213 p.

Wilcock R, Costley K, Cowles R, Wilson B, Southgate P 1991. Stream run-off losses and soil and grass residues of triclopyr applied to hillside gorse. New Zealand Journal of Agricultural Research 34: 351-357.

Williams PA, Winks C, Rijkse W 2003. Forest processes in the presence of wild ginger (Hedychium gardnerianum). New Zealand Journal of Ecology 27: 45-54.

Zeileis A, Kleiber C, Jackman S 2008. Regression models for count data in R. Journal of Statistical Software 27: 1-25.

Zuur A, Ieno E 2016. Beginner's guide to zero-inflated models with R. Newburgh, Highland Statistics Ltd. 414 p. 